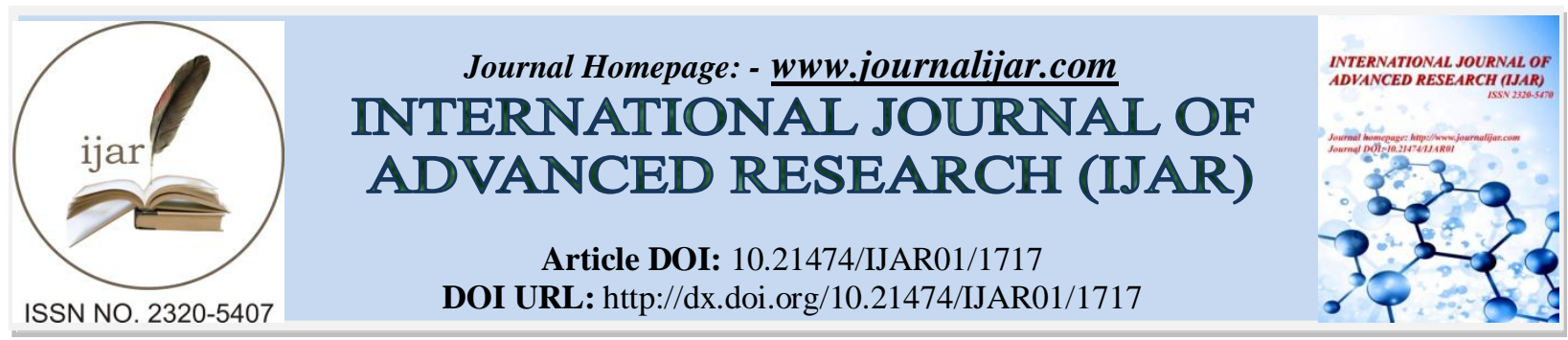

RESEARCH ARTICLE

\title{
ISOLATION OF IMMUNOMODULATORY LECTIN FROM SEEDS OF ZIZYPHUS MAURITIANA.
}

Ashwin B. Butle ${ }^{1}$ and Mandakini B. Patil ${ }^{2 *}$.

1. Research Scholar, Department of Biochemistry, RTM Nagpur University, Nagpur, LIT Premises, Amravati Road, Nagpur - 440033, India.

2. Professor and Head, Department of Biochemistry, RTM Nagpur University, Nagpur, LIT Premises, Amravati Road, Nagpur - 440033, India.

\section{Manuscript Info}

\section{Manuscript History}

Received: 12 July 2016

Final Accepted: 19 August 2016

Published: September 2016

Key words:-

Lectin, Lymphocyte proliferation,

Phagocytic activity, Lysosomal enzyme activity.

\section{Abstract}

Immunomodulation is the process in which immune response is altered either due to poor nutrition or infectious diseases. Usually the synthetic compounds as immunomodulators are employed to induce or suppress the immune system but they appear to have many adverse effects. Therefore, the use of natural compounds as immunomodulators with less or no side effects is the requirement of time. Plant lectins have been shown to have immunomodulatory activitiy. In this context, in the present study an isolated lectin from seeds of Zizyphus mauritiana was tested for its immunomodulatory activity in vitro. The lectin was isolated and purified by the standard procedures. Immunomoduatory activity was tested with sheep blood lymphocytes including MTT cytotoxicity assay, lymphocyte proliferation assay with XTT, phagocytic activity assay and lysosomal enzyme activity assay. The purified lectin was found to be tripeptide in nature. It was found that the lectin has little or no cytotoxicity towards sheep lymphocytes with maximum concentration up to 200 $\mu \mathrm{g} / \mathrm{ml}(p<0.0001)$ and effective dose was found to be $12.5 \mu \mathrm{g} / \mathrm{ml}$ $(p<0.0001)$. Lymphocyte proliferation with effective dose was found to be significantly increased as compared to controls $(p<0.0001)$ and it was found to be more than the LPS $(p<0.0001)$ and that of Con-A $(p<0.05)$ as standard mitogens. Increased phagocytic and lysosomal enzyme activity of the macrophages was observed with purified lectin $(12.5 \mu \mathrm{g} / \mathrm{ml}, p<0.0001)$ as compared to the control. Atropine solution, used as negative control, did not show any phagocytic activity $(p<0.0001)$ and lysosomal enzyme activity $(p<0.001)$. From these findings it appears that the lectin of Zizyphus mauritiana can be employed as natural immunomodulatory agent to advance human health.

Copy Right, IJAR, 2016,. All rights reserved.

\section{Introduction:-}

Immunology is one of the most rapidly developing branch of medicinal science and has great importance with regard to the prevention and treatment of a broad range of disorders. Immunomodulation is either stimulation or suppression of immune system. Immunostimulants are the agents that stimulate the response of immune system 
while immunosuppressants are those agents which suppress an immune response. Immunomodulators are natural or synthetic substances which help to regulate or normalize the immune system (Patil et al., 2012).

The immune system is the most versatile biological system of body. The basic role of immune system is to differentiate between the self from non-self in host body (Patchen et al., 1987). The immune responses of human body are of two types, an innate (natural or non-specific) and the other is adaptive (acquired or specific). Both these responses have two components each, viz. cellular and humoral (Benny and Vanitha, 2004). The leukocytes in innate response act as weapons of an immune system keeping them in a highly prepared state for encounter with non-self. Leukocytes are of two types: granulocytes (neutrophils, eosinophils and basophils) and agranulocytes (Tlymphocytes, B-lymphocytes and monocytes) (Abbas et al., 2000). The innate responses use phagocytic cells: neutrophils, monocytes, and macrophages, cells that release inflammatory mediators: basophils, mast cells, and eosinophils and natural killer cells. The molecular components of innate response include complement, acute-phase proteins and cytokines such as the interferons. Acquired immune responses involve the proliferation of $\mathrm{B}$ and $\mathrm{T}$ cells, which occur when the antigen binds to the surface receptors of these cells (Delves and Roitt, 2000).

Phagocytosis by the leukocytes is major event that occurs as immune response shown by neutrophils or macrophages. These phagocytes are having specialized receptors to recognize specific antigen; this complex machinery mediates degradative mechanisms that terminate in killing and disposal of engulfed antigens. Elimination of antigen in phagolysosome takes place by reactive oxygen species, reactive nitrogen species, anti microbial proteins (proteases, elastases, lysozyme), anti microbial peptides (defensins form pore in bacterial membrane), binding protein (lactoferrin), acidification. Another method of magrophage to kill pathogens is opsonization in which antibody functions as an opsonin, a molecule that binds to both antigen and macrophage and enhances phagocytosis with the help of lysosomal enzymes (Kindt et al., 2007; Lee et al., 2003).

The traditional Indian medicinal plants supposed to promote physical and mental health, improve defense mechanisms of body. The use of these plants causes lesser number of side effects against synthetic immunomodulatory agents (Nagarathna et al., 2013). Lectins are glycoproteins or proteins, widely distributed in nature including microorganisms, plants, animals and humans, acting as mediators of a wide range of biological events that involve the crucial step of protein-carbohydrate recognition, such as cell communication, host defense, fertilization, cell development, parasitic infection, tumor metastasis, inflammation, etc. (Sharon N, 2007; Cavada et al ., 2001). It was found that plant lectins are also the best immunomodulatory agents for proliferation of immune cells (de Melo et al., 2010; de Oliveira Silva et al., 2011), to enhance phagocytosis, expression of various cytokines (Lee et al., 2007) and proliferation of splenocytes (de Oliveira Silva et al., 2011). Lectins also have antibacterial and antifungal activity (Islam et al., 2009; Bennett and Roberts, 2005), pro-healing activity (Brustein et al., 2012; Neto et al., 2011), and activation of mechanisms of apoptosis in abnormal cells (Fiocchi, 2011), etc.

Some examples of synthetic immunomodulators and their side effects have been reported such as, Glucocorticoids: Growth retardation in children, bone's avascular necrosis, osteopenia, risk of infection, poor wound healing, cataracts, hyperglycemia, and hypertension (Sharma and Sharma, 2007; Jain, 2008; Golan, 2008; Saif, 2005), Cyclosporine: Renal dysfunction, nephrotoxicity, hyperuricemia, tremor, hirsutism, hypertension, hyperlipidemia, gum hyperplasia, hyper-cholesterolemia, hypertension, diabetogenic, Elevated LDL (Sharma and Sharma , 2007; Hilal-Dandan and Brunton, 2008; Katzung and Trevor , 2009; Jain, 2008; Tortora and Derrickson, 2008; Chaudhuri, 2001), Tacrolimus: Nephrotoxicity, neurotoxicity, GI complaints, hypertension, hyperkalemia, hyperglycemia, and diabetes (Hilal-Dandan and Brunton, 2008; Sengupta, 2009; Singhal, 2007), Sirolimus: increase in serum cholesterol and triglycerides, impaired renal function, delayed graft function, Lymphocele, anemia, leukopenia (Hilal-Dandan and Brunton, 2008; Katzung and Trevor , 2009; Panda, 2000), Azathioprine and Mycophenolate mofetil: Bone marrow suppression, leukopenia, thrombocytopenia, anemia, susceptibility to infections (viruses), hepatotoxicity, alopecia, GI toxicity, pancreatitis, sepsis associated with cytomegalovirus, in combination with mycophenolate mofetil has been associated with devastating viral infections including polyoma nephritis (Sharma and Sharma , 2007; Katzung and Trevor, 2009; Rang and Dale, 2007; Richar and Pamela, 2009), Cyclophosphamide: Pancytopenia and hemorrhagic cystitis, graft versus- host syndrome, nausea, vomiting, cardiac toxicity and electrolyte disturbances (Hilal-Dandan and Brunton, 2008; Mythili and Nair, 2004), Levamisole: Flu-like symptoms, allergic manifestation, nausea and muscle pain (Sharma and Sharma, 2007), Thalidomide: Teratogenicity (Sharma and Sharma, 2007), Isoprinosine: CNS depressant, nausea, rise of uric acid in serum and urine (Parnham MJ, and Nijkamp, 2005), Immunocynin: Rare-mild fever (Parnham, and Nijkamp, 2005) etc. 
Immunomodulators are natural or synthetic molecules that help to normalize the host immune system. Natural immunomodulators are generally less effective than synthetic immunomodulators and are also less likely to cause side effects than synthetic compounds (Patil et al., 2012). Therefore, there is a need of most potent natural immunomodulatory molecules having minor or no adverse effects in the coming decades of $21^{\text {st }}$ century. In the presented work the lectin was isolated by the standard protocols from the seeds of Zizyphus mauritiana and tested for the in vitro immunomodulatory activity (Butle and Patil, 2016).

\section{Materials and methods:- \\ Materials:- \\ Plant Material:-}

The plant was authenticated by the taxonomist of the region (Voucher No.: 9351). Fruits of Zizyphus mauritiana were collected in fruiting season from single tree growing in the forest of Gadchiroli district in Maharashtra (India). Seeds were dried and cotyledons were removed at the time of experiment.

\section{Blood Samples:-}

Rabbit blood samples were collected for the estimation of hemagglutination activity of lectin with rabbit erythrocytes. Rabbit blood was collected (following instructions of CPCSEA, Govt. of India) from Departmental Animal and Breeding House, University Department of Biochemistry; RTM Nagpur University, Nagpur (MS), India.

Sheep blood (for the isolation of lymphocytes) was obtained from the Animal Husbandry Department of Veterinary Collage, Nagpur (India). Blood was collected in heparinized vials for isolation of lymphocytes.

\section{Cell Culture Medium:-}

Histopaque 1077, Dubecco's phosphate buffered saline (DPBS), RPMI-1640, Fetal calf serum (FCS) were purchased from Gibco laboratories. Antibiotic antimycotic solution, phosphate buffer saline, lipopolysaccharide (LPS), Concanavlin-A (Con-A), MTT reagent (Tetrazolium dye 3-[4,5 - dimethylthiazol -2-yl]-2, 5-diphenyl tetrazolium bromide), XTT reagent (Sodium 2,3,-bis [2-methoxy-4-nitro-5-sulphonyl]-5-[phenylamino] carbonyl 2H- tetrazolium), N-methyl dibenzopyrazine methyl sulphate (PMS), Zymosan-A and all the cell culture medium procured from Sigma Aldrich (St. Louis, USA).

\section{Reagents:-}

Guar-gum, DEAE- cellulose, D-galactose, NaCl, SDS, Acrylamide, N-N-Methylene bisacrylamide, ammonium persulphate, Tetramethylendiamine, Glycine, Tris-hydroxy-methyl aminomethylene diamine, Bromophenol blue, Glycerol, Coomassie brilliant blue, Glacial acetic acid, Methanol, Sodium carbonate, Copper sulphate, Dimethyl sulphoxide, Potassium sulpoxide, Sodium borate, borax, Nitroblue tetrazolium (NBT), para- Nitrophenyl phosphate (pNPP), Triton X-100, Sodium citrate, Citric acid were obtained from Sigma chemicals, St Louis M. O.,USA. Native (PMWN 623110600011730) and SDS-low molecular weight protein markers were purchased from Genei, Bangalore.

\section{Methods:- \\ Isolation and Purification of lectin:-}

Isolation and purification of lectin from cotyledons of Zizyphus mauritiana was done as described earlier (Butle and Patil, 2016). Cotyledons were crushed in mortar pestle using liquid nitrogen treatment and homogenized with 0.02M sodium phosphate buffered saline (PBS) at $\mathrm{pH}$ 7. Proteins in crude extract were precipitated by ammonium sulphate at 0 to $35 \%$ concentration, solubilized in small volume of extraction medium and dialyzed against same for $14 \mathrm{~h}$ at $4{ }^{\circ} \mathrm{C}$ and designated as ammonium sulphate fraction (ASF) (Appukuttan et al.,1977). Three ml ASF was loaded on affinity column ( $3 \mathrm{~g}$ guar gum packed in $10 * 0.5 \mathrm{CM}$ long column). The bound proteins were eluted from the column by the extraction solution containing 0.4 M galactose and dialyzed as previously described (Appukuttan et al.,1977).

The eluted fractions showing maximum agglutination were further purified through an ion exchange chromatography on DEAE-cellulose (ALI et al., 2012; Nisha et al., 2013). DEAE cellulose column was eluted at the rate of $1 \mathrm{ml} / \mathrm{min}$ with a $\mathrm{NaCl}$ gradient from $0.05-0.25 \mathrm{M}$ and the absorbance of eluted fractions was measured at 280 $\mathrm{nm}$ spectrophotometrically (Eppendorf AG 2331). Ion-Exchange Chromatography fractions (IEF) were analyzed for protein estimation by the method of Lowry et al., (1951) and agglutination activity. Fractions showing maximum 
agglutination then tested for homogeneity and molecular weight determination by Native and SDS - PAGE (Waber and Obsborn, 1969).

\section{Methods for in vitro immunomodulatory activity:- Isolation of lymphocyte from sheep blood:-}

Five $\mathrm{ml}$ of sheep peripheral blood collected into heparin-containing bottles was mixed in the ratio of 1:1 with complete RPMI-1640 medium (containing 10\% heat inactivated fetal calf serum (FCS) supplemented with antibiotic-antimycotic solution). The diluted blood was then layered over Histopaque1077 gradient (Sigma, St. Louis, M.O.), and centrifuged at $400 \mathrm{~g}$ for $40 \mathrm{~min}$. Lymphocytes (PBLs) were harvested from interphase white layer, and washed thrice with complete RPMI medium. The lymphocyte concentration was adjusted to1x $10^{6}$ cells/ml. The suspension was considered as macrophage suspension for phagocytic and lysosomal enzyme activity assay. Viability of cells was determined by trypan blue dye exclusion, and was consistently greater than $96 \%$ (Kainthala et al., 2006).

\section{MTT assay for effective concentration of lectin:-}

The MTT assay was performed to assess the cytotoxic effects of the lectin on isolated lymphocytes. This assay evaluates cell viability based on the reduction of MTT by mitochondrial succinate dehydrogenase enzyme of the viable cells to a purple formazan product (Mosmann, 1983). The cells were suspended in growth medium (complete RPMI 1640) and seeded in 96-well plates at a density of $2 \times 10^{6}$ cells/well and incubated at $37^{\circ} \mathrm{C}$ for $24 \mathrm{~h}$ to attain $80 \%$ confluence. Stock concentration of lectin dissolved in PBS and made to a final concentration ranging from 1.5 to $200 \mu \mathrm{g} / \mathrm{mL}$ was prepared. Cells were exposed to the standard concentrations LPS and Con-A (10 $\mu \mathrm{g} / \mathrm{mL}$ and 5 $\mu \mathrm{g} / \mathrm{mL}$ respectively) serving as a standard control and PBS with cells as a positive control (PC).The plates were incubated with $5 \% \mathrm{CO}_{2}$ and $40 \%$ humidity at $37^{\circ} \mathrm{C}$ for 24,48 , and $72 \mathrm{~h}$ in $\mathrm{CO}_{2}$ incubator (Thermo Scientific, Class100). After incubation, a volume of $50 \mu \mathrm{L}$ of MTT $(5 \mathrm{mg} / \mathrm{mL})$ was added in every well and and the plates were incubated at $37^{\circ} \mathrm{C}$ for $4 \mathrm{~h}$. The media was aspirated and cells were washed with phosphate-buffered saline (PBS). The cells were dissolved in $100 \mu \mathrm{L}$ DMSO and absorbance was measured at $570 \mathrm{~nm}$ using a microtiter-plate reader (Thermo electron corp., 358) (Frehney, 1987). The viability of cells expressed as lymphocyte proliferation stimulation index (LSI), was calculated as:

LSI = O. D. of Experimental / O. D. of control

\section{XTT assay for proliferation of lymphocytes:-}

Effect of lectin on lymphocyte proliferation was tested by XTT assay (Kainthala et al., 2006). Lymphocyte suspension ( $1 \times 10^{6}$ cells/well) suspended in complete RPMI 1640 medium was treated with double diluted different concentration of lectin from the effective dose dissolved in PBS. The PBS was used as a control while atropine solution was used as a negative control (NC). Two groups were treated with $10 \mu \mathrm{g} / \mathrm{ml}$ of LPS and $5 \mu \mathrm{g} / \mathrm{ml}$ of Con-A individually and considered as standards (a powerful known mitogens). After incubation for $48 \mathrm{~h}$ at $37^{\circ} \mathrm{C}$ in $5 \% \mathrm{CO}_{2}$ humidified atmosphere, the medium was removed and the adherent lymphocytes were washed twice with RPMI medium. A mixture of XTT and PMS was then introduced along with RPMI 1640 medium. Cells were then incubated for $4 \mathrm{~h}$ at $37^{\circ} \mathrm{C}$ in $5 \% \mathrm{CO}_{2}$ humidified atmosphere. Absorbance was measured at $450 \mathrm{~nm}$ using microplate reader. Lymphocyte proliferation stimulation index (LSI) was determined as:

LSI = O. D. of Experimental / O. D. of control

\section{Phagocytic activity assay:-}

Capacity of lectin to stimulate phagocytosis was tested by NBT dye reduction assay (Rainard, 1986). Macrophages (1x10 $10^{6}$ ells/well) suspended in complete RPMI 1640 medium were treated with different double diluted concentration of effective dose of lectin dissolved in PBS. Control was run with PBS (without lectin, designated as C) and atropine solution was used as a negative control (NC). After incubation for $24 \mathrm{~h}$ at $37^{\circ} \mathrm{C}$ in $5 \% \mathrm{CO}_{2}$ humidified atmosphere, medium was removed and adherent macrophages were washed twice with RPMI medium. Zymosan - A $(1 \mu \mathrm{g} / \mathrm{ml}$ in PBS) was introduced along with NBT solution $(1.5 \mathrm{mg} / \mathrm{ml}$ of PBS $)$ and cells were incubated for $60 \mathrm{~min}$ at $37^{\circ} \mathrm{C}$ in $5 \% \mathrm{CO}_{2}$ humidified atmosphere. After $60 \mathrm{~min}$, medium was removed and cells were washed twice with PBS and air dried. Finally, $2 \mathrm{M} \mathrm{KOH}$ was added and absorbance was measured at $570 \mathrm{~nm}$ using micro plate reader. Phagocytic index (PI) was calculated by following equation:

$\mathrm{PI}=\mathrm{O}$. D. of Experimental / O. D. of control 
Lysosomal enzyme activity assay:-

Ability of lectin to stimulate lysosomal enzyme activity (acid phosphatase) was tested using pNPP assay (Suzuki et al., 1988). Macrophages $\left(1 \times 10^{6}\right.$ cells/well) suspended in complete RPMI 1640 medium and were treated with different concentration of lectin from the observed effective dose in MTT assay dissolved in PBS. Control was run with PBS (without lectins) and atropine solution was used as NC. After incubation for $24 \mathrm{~h}$ at $37^{\circ} \mathrm{C}$ in $5 \% \mathrm{CO}_{2}$ humidified atmosphere, medium was removed and adherent macrophages were washed twice with RPMI medium. 1 $\%$ Triton X-100, $10 \mathrm{mM}$ pNPP and $0.1 \mathrm{M}$ citrate buffer (pH 5.0) were then introduced and cells were incubated for $37{ }^{\circ} \mathrm{C}$ in $5 \% \mathrm{CO}_{2}$ humidified atmosphere. After $30 \mathrm{~min}, 0.2 \mathrm{M}$ borate buffer (pH 9.8) was added and absorbance was measured at $405 \mathrm{~nm}$ using microplate reader. Lysosomal enzyme activity index (LI) was calculated according to equation:

$\mathrm{LI}=$ O. D. of Experimental / O. D. of control

\section{Statistical analysis:-}

Each experiment with lymphocytes was run in triplicate, and the results are expressed as their mean \pm SD (standard deviation). The data was compared and analyzed using student's ' $t$ ' test. $P \leq 0.0001$ was considered as significant. All the graphs were plotted by 'Sigma Plot 10.0 ' software and statistical analysis was done with 'MedCalc 10' software.

\section{Result and Discussion:-}

Isolation and Purification of lectin:-

The lectin was purified from $0-35 \%$ ammonium sulphate fraction on guar gum was principally based on affinity binding towards the ligand D-galactose. The $0.20 \mathrm{M}$ concentration was found to be suitable for elution of lectin on DEAE-cellulose on ion-exchange chromatography and gives maximum agglutination and single band on non denaturing PAGE confirming purity of lectin. Table 1 show that the lectin was purified in the good yield (22\%) with specific activity 17066 with $20480 \mathrm{HAU} / \mathrm{ml}$. The positive phenol sulphuric acid test of the isolated lectin shows attached carbohydrate moiety in the structure of the lectin indicating glycoprotein nature of the purified lectin.

Table 1:- Summary of purification procedure of Zizyphus mauritiana seed lectin.

\begin{tabular}{|c|c|c|c|c|c|c|}
\hline $\begin{array}{c}\text { Purification } \\
\text { step }\end{array}$ & $\begin{array}{c}\text { Volume } \\
(\mathbf{m l})\end{array}$ & $\begin{array}{c}\text { Proteins } \\
(\mathbf{m g} / \mathbf{m l})\end{array}$ & HAU $^{\mathbf{a}}$ & $\mathbf{S A}^{\mathbf{b}}$ & $\begin{array}{c}\text { Purification } \\
\text { fold }\end{array}$ & Yield \% \\
\hline ASP & 100 & 15.4 & 5120 & 332.46 & 1 & 100 \\
\hline ACF & 23 & 7.76 & 10240 & 1319.58 & 3.96 & 46 \\
\hline IEF & 10 & 2.16 & 20480 & 9941.74 & 29.90 & 40 \\
\hline ASP & 6 & 1.2 & 20480 & 17066.6 & 51.33 & 22 \\
\hline
\end{tabular}

HAU: Hemagglutination Unit, b) SA: Specific Activity

ASP: Ammonium Sulphate Precipitated Fraction

ACF: Affinity Chromatography Eluted Fraction

IEF: Ion Exchange Chromatography Eluted Fraction

HAU: Reciprocal of last dilution of lectin which gives visible agglutination with rabbit erythrocytes

The homogeneity of isolated lectin was checked on $10 \%$ Non denaturing PAGE. Figure A-1 shows native gel electrophoresis of standard proteins (Native PAGE Molecular Weight Maker, Genei, Lane 1- 4) along with purified lectin (lane 5) where the purified lectin shows single band. The single band on the non denaturing PAGE confirms homogeneity of the isolated lectin. The three bands of isolated lectin on 10\% SDS-PAGE in figure 1, A-2 of lane 1 indicates the lectin to be tripeptide in nature having molecular weigh $38 \mathrm{kD}, 25 \mathrm{kD}$ and $19.95 \mathrm{kD}$ for each polypeptide chain. 


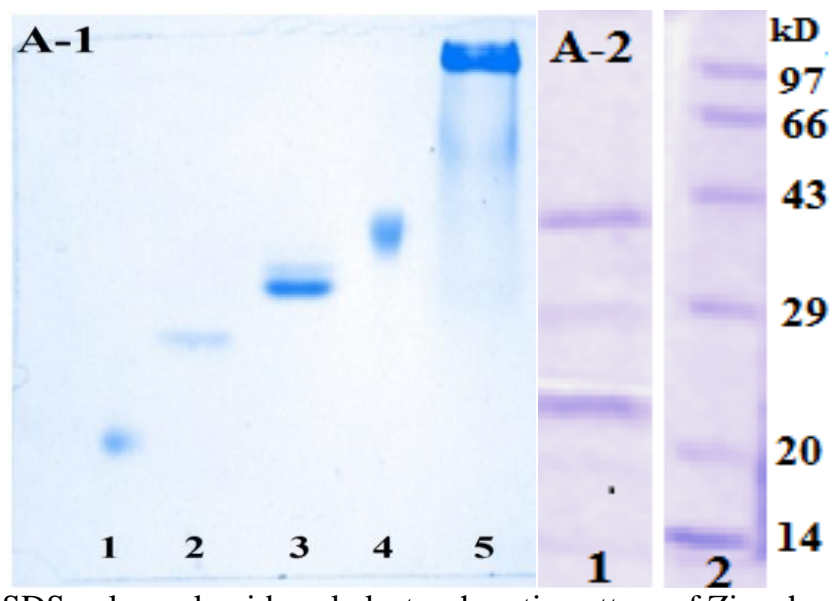

Figure 1:- Native and SDS polyacrylamide gel electrophoretic pattern of Zizyphus mauritiana seed lectin.

(Figure, A-1;Lane1: Lactoglobulin, Lane 2: Soybean Trypsin Inhibitor, Lane 3: Egg Albumin, Lane 4: Bovine Serum Albumin, Lane 5: Z.M. Lectin. In figure A-2; lane 1:isolated lectin, lane 2: SDS - Molecular weight marker).

\section{Isolation of lymphocyte from sheep blood:-}

White interphase layer of sheep blood was separated from density gradient medium and washed thrice with complete RPMI 1640 medium. Concentration of cells was calculated by 'Improved Neubauer Chamber'. The reactivity of the trypan blue is based on the fact that the chromophore is negatively charged and does not interact with the cells unless the membrane is damaged, therefore all the cells which exclude the dye are viable (Freshney, 1987). Trypan blue is a diazo dye and used as a vital stain specifically to color dead cells ('Trypan blue', www.wickipedia.com). Viability of cells by trypan blue dye exclusion was observed consistently greater than $96 \%$. Maximum viability of cells has been found in medium indicates better isolation and suitable concentration of ingredients in complete RPMI 1640 medium for lymphocyte growth.

\section{MTT assay for effective concentration of lectin:-}

Very few lectins from plants possess the unique capacity to induce inactive lymphocytes to grow and divide, a phenomenon known as mitogenic stimulation (Kilpatrick, 1999). Mitogenic lectins copy the action of antigens on lymphocytes, except that they activate a large proportion (as much as 70-80\%) of the cells, whereas antigens stimulate only specific clones, each of which cooperate a minute proportion, $0.1 \%$ or less, of the total lymphocytes (Ashraf and Khan, 2003). The isolated lectin was found to be fairly effective at dose $12.5 \mu \mathrm{g} / \mathrm{ml}\left({ }^{*} p<0.0001\right)$ in stimulating lymphocyte proliferation. In figure 2 it was observed that the little or no cytotoxic effect by the isolated lectin above the effective dose $\left(25-200 \mu \mathrm{g} / \mathrm{ml},{ }^{*} p<0.0001\right)$. The proliferation index at higher concentration was not increased as the standard mitogens (LPS and Con-A, $* p<0.0001$ ) but comparatively more than PC. The proliferation index of lymphocyte at lower concentration of lectin than the effective dose $\left(6.15-1.5 \mu \mathrm{g} / \mathrm{ml},{ }^{*} p<0.0001, \# p>0.05\right)$ was found to give dose dependent (Fig 2). Related study was done with lectin of Phaseolus vulgaris possessing an ability to stimulate lymphocytes to undergo mitosis (Sharon, 2007). 


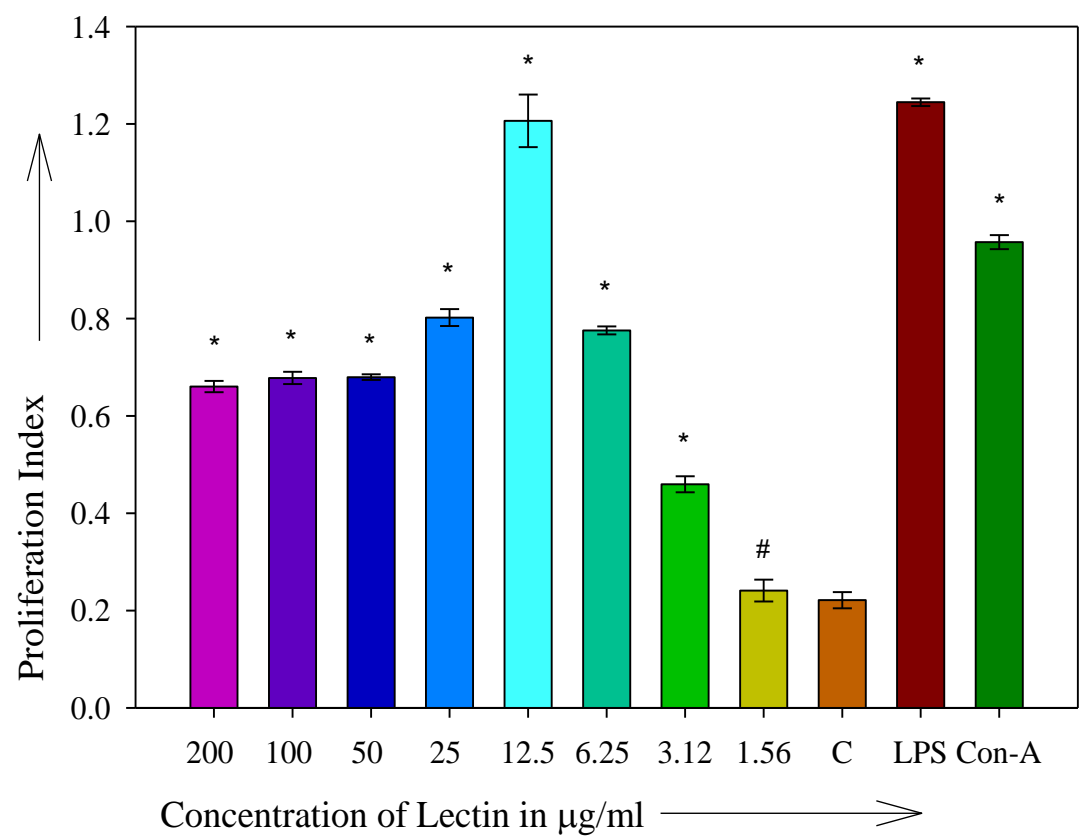

Figure 2:- MTT assay for determination of effective concentration of Zizyphus mauritiana seed lectin with lymphocytes.

In figure, $\mathrm{C}$ was compared with all different dilutions of isolated lectin, LPS and Con-A where, ${ }^{*} \mathrm{p}<0.0001$, $\$ p<0.001, @ p<0.05, \# p>0.05$

\section{XTT assay for proliferation of lymphocytes:-}

In the XTT assay (Fig 3), it was observed that the effective dose of isolated lectin significantly proliferate the lymphocytes and comparable with PC $\left({ }^{*} p<0.0001\right)$. The proliferation index of effective dose of lectin gives increased proliferation than standard known mitogens (LPS and Con-A, $* p<0.0001$, \#p<0.05 respectively). Dose dependent decreased proliferation index was observed with double diluted concentration of lectin (@ $p=0.001$, $\# p<0.05, \$ p>0.05)$. The result depicts the proliferative potential of lectin isolated from the seeds of Zizyphus mauritiana. Simillar results were found with the lectin of the red kidney bean known as phytohemagglutinin (PHA), possessing the ability to proliferation of lymphocytes (de Oliveira Silva et al., 2011), tuber lectin of wild cobra lily (Singh et al.,2004), red kidney bean lectin (Xia and Ng, 2006), mushroom lectins (Ngai and Ng, 2004); ,Ho et al., 2004), Brazilian camaratu bean lectin (Maciel et al., 2004), and jackfruit seed lectin (Pineau et al., 1990), etc. 


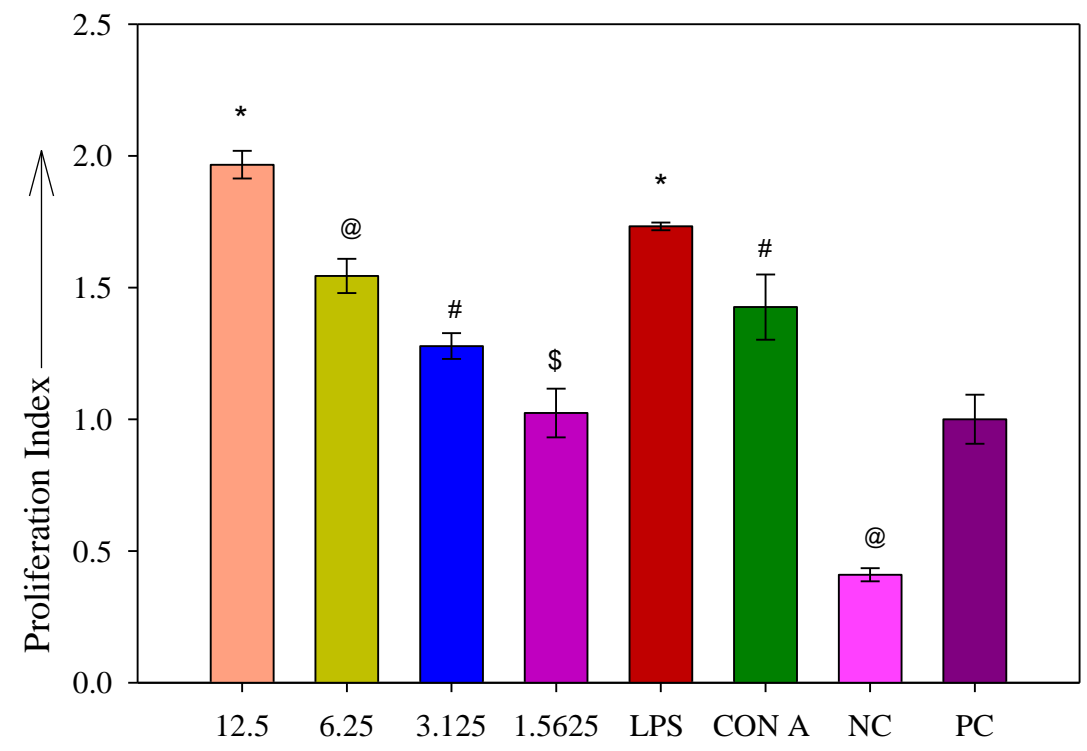

Concentration of Lectin in $\mu \mathrm{g} / \mathrm{ml} \longrightarrow$

Figure 3:- Effect of Zizyphus mauritiana seed lectin on lymphocyte proliferarion by XTT assay.

In figure, $\mathrm{C}$ was compared with all different dilutions of isolated lectin, LPS, Con-A and NC where, ${ }^{*} \mathrm{p}<0.0001$, $@ \mathrm{p}=0.001, \# \mathrm{p}<0.05, \$ \mathrm{p}>0.05$.

\section{Phagocytic activity assay:-}

Phagocytosis by the phagocytic cells is the first weapon of the immune system in cellular immune response to kill or degrade the antigen (Kindt et al., 2007). Many studies have been performed to evaluate the role of lectins in stimulation of cytokine secretion (Lee et al., 2007; Rabinovich et al ., 2007) and functional activation of monocytic and macrophage-like cells (Melo et al., 2010). Purified lectin from seeds of Zizyphus mauritiana was explored for its phagocytosis stimulating activity at different concentrations by dissolving it in PBS. It was observed that the effective concentration has shown its maximum activity ( ${ }^{*}<<0.0001$, Fig 4$)$. Atropine, a standard alkaloid used as negative control did not show any considerable significant activity. From the result of phagocytic activity assay it was confirmed that the lectin from seeds of the Zizyphus mauritiana causes an increase in the phagocytic activity. Similarly lectin isolated from Bauhinia variegata seeds has been considered as potent chemotactic agents for neutrophils through the release of cytokines (Neto et al., 2011). 


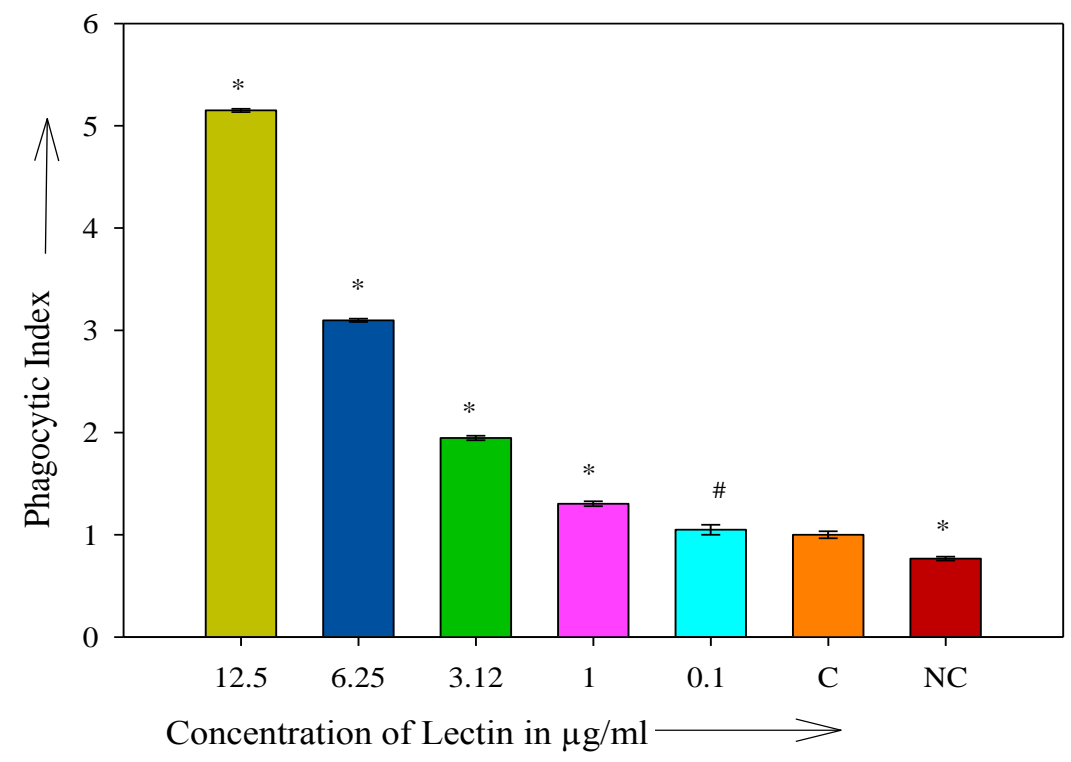

Figure 4:- Effect of Zizyphus mauritiana seed lectin on phagocytic ativity.

In figure, $\mathrm{C}$ was compared with all different dilutions of isolated lectin and $\mathrm{NC}$ where, ${ }^{*} \mathrm{p}<0.0001, \# \mathrm{p}<0.05$.

\section{Lysosomal enzyme acticity assay:-}

The lectin shows dose dependent increase in the activity of lysosomal enzymes. At an effective concentration, the lysosomal enzyme activity has shown an increase of more than double as compared to controls $\mathrm{PC}$ and $\mathrm{NC}$ $\left({ }^{*} p<0.0001\right.$, \#p>0.01, Fig 5). The Atropine used as a negative control shows no effect on enzyme activity. It was studied that enzymes and mediators of inflammation usually sequestered within lysosomes are released from viable polymorphonuclear leukocytes (PMNs) during phagocytosis (Goldstein et al., 1973). Galactose binding non toxic plant lectins was found to be very effective for cells of several organs of body in lysosomal storage disease (Radin and Jonesboro, 2013). Glycan binding lectins like galectin-8 also found to activate lysosomal enzymes in the antigen degradative pathways of the cell (Lichtenstin and Rabinovich ., 2013). 


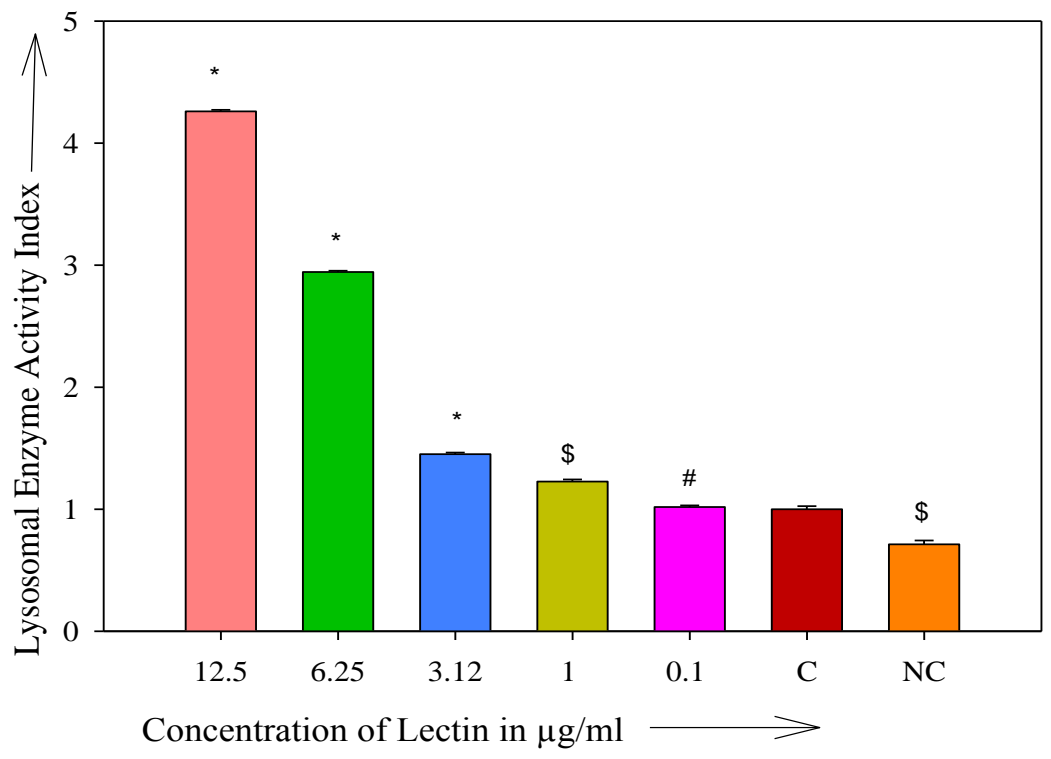

Figure 5:- Effect of Zizyphus mauritiana seed lectin on lysosomal enzyme activity.

Figure, $\mathrm{C}$ was compared with all different dilutions of isolated lectin and $\mathrm{NC}$ where, ${ }^{*} \mathrm{p}<0.0001, \$ \mathrm{p}<0.001, \# \mathrm{p}>0.01$.

\section{Conclusion:-}

As per the results presented above lectin from the seeds of Zizyphus mauritiana was isolated and purified to homogeneity. The isolated lectin was tripeptide and did not show cytotoxic effect with lymphocytes. This lectin was shown to have great impact in stimulating phagocytosis in a dose dependent manner. These results were supported by lysosomal enzyme activity assay which indicate an immunostimulation in positive direction. The isolated lectin was found to be efficient and being natural, the chances of side effect are less if employed as an immunostimulating agent in vivo.

\section{Ackwnoledgement:-}

Authors are thankful to Head Department of Biochemistry, RTM Nagpur University Nagpur for laboratory facilities and to University Grants Commission, New Delhi for funding this research project (F. No. 41/2012/1262; July 26, 2012).

\section{References:-}

1. Abbas, A.K., Lichtman A.H. and Pober J.S. (2000). Cellular and molecular immunology. $4^{\text {th }}$ Edition, Saunders, Philadelphia, ISBN-10: 0721682332, pp: 553.

2. ALI, A., Jabir, A.S., Raghda, S.A. (2012). Purification and characterization of amylase inhibitor extracted from white kidney bean (Phaseolus vulgaris). J. Cell Plant Sci., 3: 17-21.

3. Appukuttan, P.S., Surolia, A., Bacchawat, B.K. (1977). Isolation of two galactose- binding proteins from Ricinus Comunis by affinity chromatography. Indian J Biochem and Biophys., 14: 382-384.

4. Ashraf, M.T. and Khan, R.H. (2003). Mitogenic lectins. Med. Sci. Monit., 9: 265-269.

5. Bennett, H.J., Roberts, I.S. (2005). Identification of a new sialic acid-binding protein in Helicobacter pylori. FEMS Immunol. Med. Microbiol. 44: 163-9.

6. Benny, K.H., Vanitha J. (2004) Immunomodulatory and antimicrobial effects of some traditional chinese medicinal herbs: A review. Curr. Med. Chem. 11: 1423-1430.

7. Brustein, V.P., Souza-Araujo, F.V., Vaz, A.F., Araujo, R.V., Paiva, P.M., Coelho, L.C., Carneiro- Leao, A.M., Teixeira, J.A., Carneiro-da-Cunha, M.G., Correia, M.T. (2012). A novel antimicrobial lectin from Eugenia malaccensis that stimulates cutaneous healing in mice model. Inflammopharm., 20(6):315-22. 
8. Butle, A.B. and Patil, M.B. (2016). Isolation and characterization of lectin from seeds of Zizyphus mauritiana. World J.Pharma. Res., 5(8): 1314-1329.

9. Cavada, B.S., Barbosa, T., Arruda, S., Grangeiro, T.B., Barral-Netto, M. (2001). Revisiting proteus: do minor changes in lectin structure matter in biological activity? Lessons from and potential biotechnological uses of the Diocleinae subtribe lectins. Curr. Prot. Pept. Sci. 2: 123-135.

10. Chaudhuri, S.K. (2001). Quintessence of Medical Pharmacology . $2^{\text {nd }}$ edition, pp. BMJ Publish- ing Group, 103106.

11. de Melo, C.M., de Castro, M.C., de Oliveira, A.P., Gomes, F.O., Pereira, V.R., Correia, M.T., Coelho, L.C., Paiva, P.M. (2010). Immunomodulatory response of Cramoll 1,4 lectin on experimental lymphocytes. Phytother Res., 24: 1631-6

12. de Oliveira Silva, F., das Neves Santos, P., de Melo, C.M., Teixeira, E.H., de Sousa Cavada, B., Arruda, F.V., Cajazeiras, J.B., Almeida, A.C., Pereira, V.A., Porto, A.L. (2011). Immunostimulatory activity of ConBr: a focus on splenocyte proliferation and proliferative cytokine secretion. Cell Tissue Res., 346: 237-44.

13. Delves, P.J. and Roitt I.M. (2000). The immune system, The New Eng. J. Med. 343(1): 37-49.

14. Fiocchi, C. (2011). Early versus late immune mediated inflammatory diseases. Acta Gastro. Belg. 74: 548-52.

15. Frehney, R. (1987). Culture of animal cells: A manual of basic technique, Alan R. Liss, Wiley online library, Inc., New York, USA, pp. 523-524, pp 117.

16. Golan, D.E. (2008). Principles of Pharmacology. The Pathophysiologic Basic of Drug Therapy. $2^{\text {nd }}$ edition, Lippincott, pp. 795-809.

17. Goldstain, I., Hoffstein, S., Gallint, J., Weissmann, G. (1973). Mechanisms of lysosomal enzyme release from human leukocytes: Microtubule assembly and membrane fusion induced by a component of complement, Proc. Nat. Acad. Sci. USA,70(10): 2916-2920.

18. Hilal-Dandan R., Brunton, L., Goodman \& Gilman's. (2008). Manual of Pharmacology and Therapeutics, Professor of Pharmacology \& Medicine University of California, $5^{\text {th }}$ edition, San Diego LaJolla, California, pp. 262-279. (Randa Hilal-Dandan, Laurence Brunton)

19. Ho, J.C.K., Sze, S.C.W., Shen, W.Z., Liu, W.K. (2004). Mitogenic activity of edible mushroom lectins. Bioch. Biophysica Acta (BBA)., 1671: 9-17.

20. Islam, B., Khan, S.N., Naeem, A., Sharma, V., Khan, A.U. (2009). Novel effect of plant lectins on the inhibition of Streptococcus mutans biofilm formation on saliva-coated surface. J. App.1 Microbiol., 106(5): 1682-9.

21. Jain, S. (2008). Handbook of Pharmacology. $3^{\text {rd }}$ edition, Pars Publication, pp. 595-609.

22. Kainthla, R.P., Kashyap, R.S., Deopujari, J.Y., Purohit, H.J., Taori, G.M., Daginawala, H.F. (2006). Effect of Hemidesmus indicus (Anantmool) extract on $\mathrm{IgG}$ production and adenosine deaminase activity of human lymphocytes in vitro. Ind. J. Pharmacol. 38(3): 190 - 193.

23. Katzung, G.B., Trevor, J.A. (2009). Basic and Clinical Pharmacology. $11^{\text {th }}$ edition, McGraw Hill Professional, pp. 363-435.

24. Kilpatrick, D.C. (1999). Mechanisms and assessment of lectin-mediated mitogenesis. Mol. Biotechnol., 11:5565

25. Kindt, T.J., Goldsby R.A., Obsborn, A.B. (2007). Kuby Immunology. $6^{\text {th }}$ edition, W. H. Freeman and Company, New York.

26. Lee, J.Y., Kim, J.Y., Lee, Y.G., Byeon, S.E., Kim, B.H., Rhee, M.H., Lee, A., Kwon, M., Hong, S., Cho, J.Y. (2007). In vitro immunoregulatory effects of Korean Mistletoe lectin on functional activation of monocytic and macrophage-like cells. Biol. Pharm. Bull., 30: 2043-2051.

27. Lee, W.L., Harrison, R.E., Grinstein, S. (2003). Phagocytosis by neutrophils, Microb. Infec. 5: 1299-1306.

28. Lichtenstin, R.G. and Rabinovich G.A. (2013). Glyobiology of cell death: When glycans and lectins govern cell fate. Cell Death and Diffrentiation; Nature, 20: 976-986.

29. Lowry, O.H., Rosebrough, N.J., Farr, A.L., Randall, R.J. (1951). Protein measurement with the Folin phenol reagent. J. Biol. Che., 193: $265-275$.

30. Maciel, E.V.M., AraAojo-Filho, V.S., Nakazawa, M., Gomes, Y.M., Coelho, L.C.B.B., Correia, M.T.S. (2004). Mitogenic activity of Cratylia mollis lectin on human lymphocytes. Biolog., 32:57-60.

31. Melo, C.M.L., Paim, B.A., Zecchin, K.G., Morari, J., Chiarrati, M.R., Correia M.T.S., Coelho, L.C.B.B., Paiva, P.M.G. (2010). Cramoll 1,4 lectin increases ROS production, calcium levels and cytokine expression in treated spleen cells of rats. Mol. Cell. Biochem., 342: 163-169.

32. Mosmann T. (1983). Rapid colorimetric assay for cellular growth and survival: application to proliferation and cytotoxicity assays. J. Immuno. Meth., 65 (2): pp. 55-63. 
33. Mythili, M.D. and Nair, S.C. (2004). Effect of cyclophosphamide pretreatment on hematological indices of Indian Bonnet monkey. Indian J. Pharmacol. 36: 175-180.

34. Nagarathna, P.K.M, Reena, K., Reddy, S., Wesley, J. (2013). Review on Immunomodulation and immunomodulatory activity of some herbal plants. Int. J. Pharm. Sci. Rev. Res. 22(1): 223-230.

35. Neto, L.G., Pinto Lda, S., Bastos, R.M., Evaristo, F.F., Vasconcelos, M.A., Carneiro, V.A., Arruda, F.V., Porto, A.L., Leal, R.B., Junior, V.A., Cavada, B.S., Teixeira, E.H. (2011). Effect of the lectin of Bauhinia variegata and its recombinant isoform on surgically induced skin wounds in a murine model. Molecules. 16: 9298-315.

36. Ngai, P.H.K. and Ng, T. B. (2004) A mushroom (Ganoderma capense) lectin with spectacular thermostability, potent mitogenic activity on splenocytes, and antiproliferative activity toward tumor cells. Biochem. Biophys. Res. Commun., 314:988-993.

37. Nisha, K., Veena, J., Malhotra, S. (2013). Purification and characterization of extracellular acidophilic $\alpha$ amylase from Bacillus cereus MTCC 10205 isolated from soil. Global J. Microbiol. Res., 1: 001-009.

38. Panda, U.N. (2000).Textbook of Medicine. $1^{\text {st }}$ edition, CBS Publishers, pp. 107-108.

39. Parnham, M.J. and Nijkamp, F.P. Principles of Immunopharmacology. $2^{\text {nd }}$ edition, Birkhauser Verlag, pp. $377-$ 389.

40. Patchen, M.L., D'Alesandro, M.M., Glucan, I.B. (1987) Mechanisms involved in its radioprotective effect. J. Leuk. Biol. 42: 95-105.

41. Patil, U.S., Jaydeokar, A.V., Bandawne, D.D. (2012). Immunomodulators: A pharmacological review. Int. J. Pharm. Pharmaceut. Sci., 4(1): 30-36.

42. Pineau, N., Aucouturier, P., Brugier, J.C., Preud'homme, J.L. (1990). Jacalin: a lectin mitogenic for human CD4 T lymphocytes. Clin. Exp. Immunol., 80:420-425.

43. Rabinovich, G.A., Toscano, M., Jackson, D.A., Vasta, G. (2007). Functions of cell surface galectinglycoprotein lattices. Curr. Opin. Struct. Biol., 17: 513-520.

44. Radin, D.N. and Jonesboro, A.R. (2013). Plant lectin as a carrier of associated drug substances into animal and human cells. United States, Patent application publication, App. No. 61/653,062, Pub No. US 2013/0323221A1, Dec 52013.

45. Rainard, P. (1986). A calorimetric microassay for opsonins by reduction of NBT in phagocytosing bovine polymorphs. J. Immunol. Meth., 90: $197-201$.

46. Rang, H.P. and Dale, M.M. (2007). Rang and dale Pharmacology. $6^{\text {th }}$ edition, Churchill Livingestone, Elsevier, pp. 481-488, 538-541.

47. Richar, A.H. And Pamela, C.C. (2009). Lippincott's Illustrated Reviews: Pharmacology. $4^{\text {th }}$ edition, pp. 489498.

48. Saif, S.R. (2005). Pharmacology Review. $1^{\text {st }}$ edition, CBS Publisher, 99, pp. 846-852.

49. Sengupta, P.R. (2009). Medical Pharmacology. $1^{\text {st }}$ edition, CBS Publisher, pp. 573-575.

50. Sharma, H.L., Sharma, K.K. (2007). Principals of Pharmacology. $1^{\text {st }}$ edition, Paras Medical Publishers, New Delhi, pp. 428-453.

51. Sharon, N. (2007). Lectins: Carbohydrate-specific reagents and biological recognition molecules. J. Biol. Chem., 282:2753-2764

52. Singh, J., Singh, J., Kamboj, S.S. (2004). A novel mitogenic and antiproliferative lectin from a wild cobra lily Arisaema flavum. Biochem. Biophys. Res. Commun., 318:1057-1065.

53. Singhal, K.C. (2007). Essentials of pharmacotherapeutics. $1^{\text {st }}$ edition, CBS Publishers, pp. 11-12.

54. Suzuki, I., Tanaka, H., Adachi, Y., Yadomi, T. (1988). Rapid measurement of phagocytosis in macrophages. Chemi. Pharma. Bulletin., 36: 4871 - 4875.

55. Tortora, G.J. and Derrickson, B.P. (2008). Principles of Anatomy and Physiology. 1: $12^{\text {th }}$ edition, Wiley Publication, pp. 846-852.

56. 'Trypan blue', www.wickipedia.com, Retrived from, https://en.wikipedia.org/wiki/Trypan_blue

57. Weber, K. and Osborn, M. (1969). The reliability of molecular weight determination by Sodium dodecyl sulphate polyacrylamide gel electrophoresis. J. biochem., 244: 4406-4412.

58. Xia, L. and Ng, T.B. (2006). A hemagglutinin with mitogenic activity from dark red kidney beans. J. Chromato., 844:213-216. 